\title{
Re-examining the decline in the US saving rate: The impact of mortgage equity withdrawal
}

\author{
Guglielmo Maria Caporale ${ }^{\mathrm{a}, *}$, Mauro Costantini ${ }^{\mathrm{a}}$, \\ Antonio Paradiso ${ }^{\text {b }}$ \\ a Brunel University, London, UK \\ b Ca' Foscari University of Venice, Venice, Italy
}

\section{A R T I C L E I N F O}

\section{Article history:}

Received 6 September 2012

Accepted 1 June 2013

Available online 14 June 2013

\section{JEL classification:}

C32

E21

051

Keywords:

Saving rate

Mortgage equity withdrawal

Net wealth

Mortgage interest rates

Vector error correction model

\begin{abstract}
A B S T R A C T
This paper investigates the effect of mortgage equity withdrawal on saving in the US over the period 1993-2011. A multivariate time series analysis based on a vector error correction model (VECM) is carried out. The saving rate, mortgage equity withdrawal, net wealth, interest rates and inflation are included in the empirical model. The results show that the equity withdrawal mechanism plays a relevant role in explaining the saving rate pattern.
\end{abstract}

(c) 2013 Elsevier B.V. All rights reserved.

\section{Introduction}

The US saving rate has been declining sharply since the 1990s. The personal saving rate dropped from an average of $8.6 \%$ in the period $1980-1990$ to an average of 5.5 in the period 1990-2000. The average rate has fallen to $3.5 \%$ over the period 2000-2011. This decline is now considered a stylised fact and has attracted a lot of attention from academics and policy-makers. Greenwood and Jovanovic

\footnotetext{
* Corresponding author at: Brunel University, West London UB8 3PH, UK. Tel.: +44 1895 266713; fax: +44 1895266713.

E-mail addresses: Guglielmo-Maria.Caporale@brunel.ac.uk (G.M. Caporale), Mauro.Costantini@brunel.ac.uk (M. Costantini), anto_paradiso@hotmail.com (A. Paradiso).
} 
(1999) put forward the idea that recent advances in technology and in labour productivity have led US households to revise upwards their permanent income estimates. Lusardi et al. (2001) take the view that the appreciation of assets and the increase in medical care expenditure are the causes of the drop in the personal saving rate. Muellbauer (2008) argues that significant improvements in credit access have increased the ability of households to extract or borrow against their home equity, changing the saving behaviour in many countries.

In this paper, we focus on mortgage equity withdrawal (MEW - also known as home equity extraction) as a possibly important cause of the decline in the US saving rate. This is defined as the amount of equity that is extracted from the underlying asset when it appreciates. In general, when housing wealth increases (due to a rise in house prices) and mortgage rates are low, homeowners have an incentive to withdraw housing equity (see, e.g. Duca and Kumar, 2011; Paradiso et al., 2012; Paradiso, 2013) and this may increase consumption expenditure. Smith and Searle (2008) argue that housing equity withdrawal plays a role of a buffer against unexpected events allowing households to support their consumption plans over the life-cycle; Greenspan and Kennedy (2005, 2008), and Hatzius (2006) also think that MEW has played a crucial role in determining private consumption expenditure. Empirical studies for the US show that regressions of consumption on mortgage equity withdrawal yield coefficients ranging from zero to as high as 0.62 for the long-run propensity to consume (Catte et al., 2004; Hatzius, 2006; Klyuev and Mills, 2010; Girouard, 2010). Specifically, Catte et al. (2004) find that MEW drives consumption with a marginal propensity to consume equal to 0.2 for the US when an error correction model including consumption, disposable income, net financial wealth, net housing wealth and MEW variables is estimated. Using a single equation error correction model, Hatzius (2006) finds that each dollar of MEW generates 62 cents of extra consumer spending when the consumption ratio, net wealth, interest rate and MEW are included in the analysis. Klyuev and Mills (2010) study the role of MEW in explaining the decline in the saving rate for different countries. Their empirical results for the US indicate that MEW is not statistically significant in a single equation error correction model with the saving rate, net wealth, interest rates and inflation. Girouard (2010) investigates the effects of housing wealth on the marginal propensity to consume in the US and other OECD countries and shows that they are stronger where mortgage markets are "most complete", in particular where they provide opportunities for MEW.

This paper aims to contribute to the current literature on the decline of the US saving rate over the period 1993-2011 by focusing on the role of MEW in a multivariate time series framework. In particular, the analysis improves on the earlier studies discussed above in two respects. First, a VECM model is estimated instead of a single equation error correction model. This is important since the assumption of exogeneity implicitly made in a single equation model for the right-hand side variables (see Urbain, 1992; Ericsson and MacKinnon, 2002) may not be a valid one for MEW and housing wealth (see Mishkin, 2007; Iacoviello, 2011, among others). By contrast, in the Johansen's (1988) approach used here all variables are jointly modelled in a complete closed form model, full information analysis can be carried out and the number of cointegrating vectors can be determined performing appropriate cointegration tests. Second, the estimation of a multivariate model instead of a single equation one allows to investigate the dynamic linkages between the variables using impulse response analysis, a valuable tool in cointegrated systems (see Lütkepohl and Reimers, 1992). Since in such a framework the deviations from equilibrium are stationary, they will eventually revert to equilibrium, and their time paths provide useful insights into the short-run and long-run relationships between the variables of the system. Therefore, our approach enables us to investigate both the short- and long-run impact of mortgage equity withdrawal on the saving rate.

In the empirical analysis, we consider two specifications. First, we estimate a VECM with five variables typically used in the empirical literature (see Hatzius, 2006; Klyuev and Mills, 2010), namely the saving rate, net wealth, real mortgage interest rates, inflation and MEW. Second, a VECM with disaggregate net wealth, housing and non-housing wealth, is estimated. A partition of net wealth is here considered because housing wealth is often viewed as the main determinant of consumption expenditure (Poterba, 2000; Kishor, 2007) and, after the housing bubbles of recent years, its relative weight has increased further (see Donihue and Avramenko, 2007; Iacoviello, 2011).

The empirical results show that the signs of the estimated long-run coefficients on housing wealth, real mortgage interest rates, and inflation are not significant. Since the restrictions on these coefficients 
and corresponding factor loadings are found to hold, we estimate two three-variate VECMs excluding housing wealth, inflation and real interest rates in the six-variate VAR and inflation and real interest rates in the five-variate VAR. The impulse-response analysis conducted on the two VECMs with three variables indicates that a positive shock to mortgage equity withdrawal has a significant negative effect on the saving rate, showing that mortgage equity withdrawal is an important driver of the saving pattern over the last 20 years.

The paper is organised as follows. Section 2 describes the data. Section 3 presents the empirical results. Section 4 offers some concluding remarks.

\section{Data description}

For the empirical analysis, we use quarterly data over the period 1993:Q1-2011:Q1. The series are: the saving rate, total net wealth, housing and non-housing net wealth, the real mortgage rate, inflation and mortgage equity withdrawal. The saving rate is the personal saving rate and the data have been obtained from the Bureau of Economic Analysis (BEA). Total net wealth, housing and non-housing wealth are constructed from the flow-of-funds accounts of the Boards of Governors of the Federal Reserve System and are expressed on an end-of-period basis. Therefore, throughout the analysis the $t-1$ value of the flow-of-funds data is associated with period $t$ wealth in order to obtain a start-ofperiod measure. Our source is Table B.100 of the flow-of-funds. Total net wealth is equal to total assets less total liabilities. Housing net wealth is equal to housing assets less home mortgages. Non-housing net wealth is equal to total net wealth less housing net wealth. All these measures of wealth are expressed as a percentage of disposable personal income. The data for disposable personal income are taken from the National Income and Product Accounts (NIPA).

The real interest and inflation rates are defined as in previous studies (see, e.g. Klyuev and Mills, 2010). The mortgage interest rate is used for two main reasons. First, the increase in household debt in recent years can mostly be attributed to the huge increase in house-related mortgage debt and, to a lesser extent, to pure consumer credit. ${ }^{1}$ Second, the recent innovations in the mortgage market have reduced transactions costs and increased cash-out refinancing (see Cynamon and Fazzari, 2008).

The inflation is calculated using core CPI and it is included because it can affect saving rate since uncertainty and pessimism about the future induce consumers to save more (Katona, 1975). Furthermore, a rise in inflation erodes the real values of nominal assets reducing consumption expenditures (Klyuev and Mills, 2010). ${ }^{2}$

The data for MEW is taken from Greenspan and Kennedy's (2008) data set. ${ }^{3}$ MEW is equity withdrawal extracted from the existing houses via cash-out refinancing, house equity borrowing and housing turn-over (see Greenspan and Kennedy, 2008) and comprises "active" and "passive" MEW. Active MEW consists of cash-out refinancing and house equity borrowing, that are discretionary actions to extract house equity, while passive MEW is the equity released during housing turn-over. In our analysis we consider active MEW, expressed as a ratio to disposable income, because most of the literature has shown that the saving/consumption ratio has been mainly affected by this variable. A survey conducted by the Federal Reserve Bank shows that $16 \%$ of the equity extracted through cashout refinancing was used to finance consumption (see Canner et al., 2002). Greenspan and Kennedy (2008) regard active MEW as a deliberate form of borrowing that is linked to consumer spending more strongly than passive MEW, and Disney and Gathergood (2009) and Mian and Sufi (2011) show that US households have spent most of the money they had borrowed for consumption purposes.

\footnotetext{
${ }^{1}$ Mortgage debt increased from about $60 \%$ of disposable income in the 1990 s to about $83 \%$ in the early years of this century, whilst consumer debt rose from about $17 \%$ of disposable income in 1960 to only $25 \%$. House mortgages and consumer debt represented $74 \%$ and $22 \%$ respectively of the nearly 6 trillion dollar increase in household debt between 1990 and the early 2000s (for further details, see the Federal Reserve Board (FRB) and Bureau of Economic Analysis (BEA), and Kim, 2011).

2 For other explanations of the inflation effect on consumption/saving behaviour, see Paradiso et al., 2012.

${ }^{3}$ We are grateful to Greenspan and Kennedy for providing an updated series of active MEW (1993:Q1-2011:Q1). The series is not seasonally adjusted. We have carried out the seasonal adjustment with X-12 ARIMA using the Demetra package.
} 
Table 1

Unit root test results.

\begin{tabular}{lll}
\hline Variable & ADF & DF-GLS \\
\hline$s r$ & -2.183 & -1.263 \\
$\Delta s r$ & $-11.728^{* * * *}$ & $-4.718^{* * *}$ \\
$n h w$ & -2.035 & -1.090 \\
$\Delta n h w$ & $-7.834^{* * * *}$ & $-4.075^{* * *}$ \\
$h w$ & -1.652 & -1.677 \\
$\Delta h w$ & $-3.043^{* * *}$ & $-2.556^{* *}$ \\
$n w$ & -2.174 & -1.465 \\
$\Delta n w$ & $-4.287^{* * *}$ & $-3.699^{* * *}$ \\
imor & -1.388 & -1.436 \\
$\Delta i m o r$ & $-6.503^{* * *}$ & $-5.179^{* * *}$ \\
inf & -1.639 & 0.027 \\
$\Delta i n f$ & $-3.864^{* * *}$ & $-3.746^{* * *}$ \\
amew & -2.173 & $-1.646^{*}$ \\
$\Delta$ amew & $-3.086^{* *}$ & $-3.062^{* * *}$
\end{tabular}

Notes: A model with a constant is considered. The maximum number of lags for the ADF and DF-GLS tests is selected according to the Schwert (1989) criterion. The critical values for the ADF and the DF-GLS unit root tests are tabulated in MacKinnon (1996) and Elliot et al. (1996), respectively.

* * Denotes significance at the $10 \%$ level.

**** Denotes significance at the $5 \%$ level.

****** Denotes significance at the $1 \%$ level.

\section{Empirical results}

In the empirical analysis we consider two VECMs. The first specification includes five variables: the saving rate ( $s r$ ), net wealth ( $n w$ ), the real mortgage rate (imor), the inflation rate (inf) and active MEW (amew); the second includes sr, imor, inf, amew, housing ( $h w$ ) and non-housing ( $n h w)$ wealth.

As a preliminary step, we investigate the unit root properties of the variables using the ADF and DF-GLS tests. The results are reported in Table 1 . The null hypothesis of a unit root cannot be rejected for the levels for all seven variables. We also test the null of a unit root in the first differences which can be rejected at the $1 \%$ significance level (the only exceptions are the ADF and DF-GLS results for amew and $h w$ which are both significant at 5\% level).

Since all series are $I(1)$, it is legitimate to test for cointegration. Therefore we estimate an unrestricted VAR that forms the basis for the system cointegration tests (see Lütkepohl, 2004).

For the VAR model with five variables, standard information criteria (AIC, SIC, HQ) suggest lag length one, but we opt for two lags on the basis of the residual autocorrelation tests. For the VAR with six variables, information criteria clearly suggest two lags and this is confirmed by residual autocorrelation tests.

The results of the diagnostic tests are quite satisfactory, and only slight evidence of non-normality is found for the VAR with six variables (see Table 2). However, an absolute value of unity or less for skewness is acceptable according to Juselius (2006). Furthermore, since Johansen's (1988) multivariate approach appears to be robust to excess kurtosis, non-normality does not seem to be a serious problem (see Juselius, 2001). Our results regarding univariate normality tests conducted on the VAR with six variables are in line with Juselius' $(2001,2006)$ remarks (see Table 3).

After checking for the adequacy of the two VAR specifications, we proceed to test for cointegration using the trace test proposed by Johansen (1998). The results show that the null of rank $r=1$ cointegrating vectors cannot be rejected at the conventional significance level for both model specifications (see Table 4). Therefore, for the VECM analysis we assume a single cointegrating vector for both specifications.

The estimation results of the VECMs are reported in Table 5. For the VECM with five variables, we find that that the estimated coefficient of imor has a sign contradicting the main empirical results and the coefficient of inf is not statistically significant. The reason is that active MEW may have captured part of the information already embodied in these two variables (see Duca and Kumar, 2011; Paradiso 


\section{Table 2}

Diagnostic tests for $\operatorname{VAR}(p)$ specifications.

\begin{tabular}{|c|c|c|c|c|}
\hline$p$ & $Q_{16}$ & $\mathrm{FLM}_{5}$ & $\mathrm{LJB}_{5}^{L}$ & $\mathrm{MARCH}_{L M}(4)$ \\
\hline \multicolumn{5}{|c|}{ VAR with $s r, n w$, imor, inf and amew } \\
\hline \multirow[t]{2}{*}{1} & 392.548 & 1.560 & 21.684 & 905.519 \\
\hline & {$[0.26]$} & {$[0.00]$} & {$[0.02]$} & {$[0.44]$} \\
\hline \multirow[t]{2}{*}{2} & 359.069 & 1.331 & 17.457 & 895.144 \\
\hline & {$[0.36]$} & {$[0.05]$} & {$[0.06]$} & {$[0.54]$} \\
\hline$p$ & $Q_{16}$ & $\mathrm{FLM}_{5}$ & $\mathrm{LJB}_{6}^{L}$ & $\mathrm{MARCH}_{L M}(3)$ \\
\hline \multicolumn{5}{|c|}{ VAR with $s r, h w, n h w$, imor, inf and amew } \\
\hline \multirow[t]{2}{*}{2} & 544.510 & 1.068 & 32.168 & 1347.431 \\
\hline & {$[0.10]$} & {$[0.35]$} & {$[0.00]$} & {$[0.31]$} \\
\hline
\end{tabular}

Notes: $p$-Values are in parenthesis. $Q_{h}$ indicates the multivariate Ljiung-Box Portmentau test. FLM $_{h}$ is a variant of Breusch-Godfrey LM test for autocorrelation up to order $h$. $\mathrm{LJB}_{K}^{L}$ is the multivariate Lomnicki-Jarque-Bera test for nonnormality; $\operatorname{MARCH}_{\mathrm{LM}}(q)$ is the multivariate LM test for ARCH.

Table 3

Univariate tests for normality for VAR with $s r, h w, n h w$, imor, inf and amew.

\begin{tabular}{lcccccc}
\hline Tests & nhw & hw & imor & inf & amew & sr \\
\hline Norm (2) & 2.093 & 9.655 & 3.805 & 5.070 & 2.170 & 0.126 \\
& {$[0.35]$} & {$[0.01]$} & {$[0.15]$} & {$[0.08]$} & {$[0.34]$} & {$[0.94]$} \\
Skewness & -0.07 & -0.06 & 0.41 & 0.41 & -0.39 & 0.10 \\
Excess kurtosis & 3.83 & 4.80 & 3.78 & 4.02 & 3.37 & 3.01 \\
\hline
\end{tabular}

Note: $p$-Values in brackets.

\section{Table 4}

Cointegration results.

\begin{tabular}{|c|c|c|c|c|}
\hline$H_{0}: r$ & Trace statistics & CV10 & $\mathrm{CV}$ & CV1 \\
\hline \multicolumn{5}{|c|}{ VAR with $s r, n w$, imor, inf and amew } \\
\hline$r=0$ & 79.65 & 72.74 & 76.81 & 84.84 \\
\hline$r=1$ & 44.62 & 50.50 & 53.94 & 60.81 \\
\hline$r=2$ & 20.18 & 32.25 & 35.07 & 40.78 \\
\hline$r=3$ & 6.19 & 17.98 & 20.16 & 24.69 \\
\hline$r=4$ & 2.49 & 7.60 & 9.14 & 12.53 \\
\hline \multicolumn{5}{|c|}{ VAR with $s r, h w, n h w$, imor, inf and amew } \\
\hline$r=0$ & 111.77 & 98.98 & 103.68 & 112.88 \\
\hline$r=1$ & 71.42 & 72.74 & 76.81 & 84.84 \\
\hline$r=2$ & 38.74 & 50.50 & 53.94 & 60.81 \\
\hline$r=3$ & 19.03 & 32.25 & 35.07 & 40.78 \\
\hline$r=4$ & 7.14 & 17.98 & 20.16 & 24.69 \\
\hline$r=5$ & 2.10 & 7.60 & 9.14 & 12.53 \\
\hline
\end{tabular}

Notes: Sample 1993:Q1-2011:Q1; $r$ indicates the number of cointegrating vectors; the critical values of Johansen's trace tests are obtained by computing the relevant response surface as in Doornik (1998). For the VAR with five and six variables, the deterministic terms in the model are the constant and four spike dummies (1998:Q1, 2001:Q4, 2004:Q2, 2009:Q3). The first dummy is included for the sharp rise in saving rate, while the second and fourth dummies are included for the economic recessions (burst of dotcom bubble in 2001 and global economic recession in 2009). The third dummy is included for the sharp rise in the house prices. The dummies are not restricted to the long-run.

et al., 2012; Paradiso, 2013). With respect to the other two variables ( $a m e w$ and $n w$ ), the results indicate that they both have a negative effect on the saving rate as expected (see Table 5).

As regards the VECM model with six variables, the estimated coefficients of $h w$, imor and inf are not consistent with economic theory, whereas nhw has the correct sign, although it is statistically insignificant. The wrong sign of $h w$ may be due to the fact that its effect is already picked up by amew, given the link between housing wealth and house prices; the statistical insignificance of $n h w$ is likely due to the dynamics of imor and inf reflecting the behaviour of some of the components of non-housing 
Table 5

Cointegration vector and loading parameter for VECM specifications and cointegrating rank $r=1$.

\begin{tabular}{|c|c|c|c|c|c|c|c|c|}
\hline & $n w$ & nhw & $h w$ & imor & $\inf$ & amew & $s r$ & cons \\
\hline \multicolumn{9}{|c|}{ VAR with $s r, n w, i m o r$, inf and amew } \\
\hline$\hat{\beta}^{\prime}$ & $\begin{array}{c}0.186 \\
(5.99)\end{array}$ & - & - & $\begin{array}{c}0.484 \\
(2.86)\end{array}$ & $\begin{array}{c}-0.295 \\
(-1.36)\end{array}$ & $\begin{array}{r}0.333 \\
(3.22)\end{array}$ & $\begin{array}{l}1 \\
1\end{array}$ & \multirow[t]{2}{*}{$\begin{array}{l}-15.747 \\
(-9.10)\end{array}$} \\
\hline$\hat{\alpha}^{\prime}$ & $\begin{array}{l}-0.405 \\
(-1.45)\end{array}$ & - & - & $\begin{array}{c}-0.205 \\
(-2.92)\end{array}$ & $\begin{array}{c}0.092 \\
(2.72)\end{array}$ & $\begin{array}{r}-0.178 \\
(-2.45)\end{array}$ & $\begin{array}{c}-0.388 \\
(-3.09)\end{array}$ & \\
\hline \multicolumn{9}{|c|}{ VAR with $s r, h w, n h w$, imor, inf and amew } \\
\hline$\hat{\beta}^{\prime}$ & - & $\begin{array}{c}0.033 \\
(0.64)\end{array}$ & $\begin{array}{c}-1.453 \\
(-3.26)\end{array}$ & $\begin{array}{c}0.376 \\
(1.32)\end{array}$ & $\begin{array}{c}0.509 \\
(0.98)\end{array}$ & $\begin{array}{r}2.547 \\
(4.23)\end{array}$ & $\begin{array}{l}1 \\
1\end{array}$ & \multirow[t]{2}{*}{$\begin{array}{r}3.278 \\
(0.865)\end{array}$} \\
\hline$\hat{\alpha}^{\prime}$ & - & $\begin{array}{c}0.222 \\
(1.39)\end{array}$ & $\begin{array}{c}0.056 \\
(2.83)\end{array}$ & $\begin{array}{c}-0.067 \\
(-1.55)\end{array}$ & $\begin{array}{c}0.010 \\
(0.46)\end{array}$ & $\begin{array}{c}0.004 \\
(0.09)\end{array}$ & $\begin{array}{c}-0.334 \\
(-5.03)\end{array}$ & \\
\hline
\end{tabular}

Notes: Sample 1993:Q1-2011:Q1.t-Statistics in parentheses.

Table 6

Diagnostic tests for VAR(itp) specification.

\begin{tabular}{|c|c|c|c|c|}
\hline$p$ & $Q_{16}$ & $\mathrm{FLM}_{5}$ & $\mathrm{LJB}_{3}^{L}$ & $\mathrm{MARCH}_{L M}(4)$ \\
\hline \multicolumn{5}{|c|}{ VAR with $s r, n w$ and amew } \\
\hline 3 & $\begin{array}{r}138.856 \\
{[0.08]}\end{array}$ & $\begin{array}{r}1.458 \\
{[0.06]}\end{array}$ & $\begin{array}{r}4.703 \\
{[0.58]}\end{array}$ & $\begin{array}{l}157.773 \\
{[0.20]}\end{array}$ \\
\hline \multicolumn{5}{|c|}{ VAR with $s r, n h w$ and amew } \\
\hline 3 & $\begin{array}{r}142.862 \\
{[0.05]}\end{array}$ & $\begin{array}{r}1.367 \\
{[0.09]}\end{array}$ & $\begin{array}{l}10.668 \\
{[0.10]}\end{array}$ & $\begin{array}{l}163.377 \\
{[0.13]}\end{array}$ \\
\hline
\end{tabular}

Notes: $p$-Values are in parenthesis. $Q_{h}$ indicates the multivariate Ljiung-Box Portmentau test. FLM F $_{h}$ is variant of Breusch-Godfrey LM test for autocorrelation up to order $h$. $\mathrm{LJB}_{K}^{L}$ is the multivariate Lomnicki-Jarque-Bera test for nonnormality; $\operatorname{MARCH}_{\mathrm{LM}}(q)$ is the multivariate LM test for ARCH.

wealth such as company shares and government bonds (see Bakshi and Chen, 1996; Mankiw and Ball, 2011).

Since imor, inf, and $h w$ seem to contain redundant information, we impose appropriate restrictions on the two VEC models. Specifically, we test whether their coefficients (that of $h w$ only for the sixvariate VECM) in the cointegrating vector and the factor loading are all zero. The test results imply that the restrictions hold (the $p$-value is equal to 0.17 for both models).

Table 7

Cointegration results. VAR with three variables

\begin{tabular}{|c|c|c|c|c|}
\hline$H_{0}: r$ & Trace statistics & CV10\% & CV5\% & CV1\% \\
\hline \multicolumn{5}{|c|}{ VAR with $s r, n w$ and amew } \\
\hline$r=0$ & 40.04 & 32.25 & 35.07 & 40.78 \\
\hline$r=1$ & 9.99 & 17.98 & 20.16 & 24.69 \\
\hline$r=2$ & 2.95 & 7.60 & 9.14 & 12.53 \\
\hline \multicolumn{5}{|c|}{ VAR with $s r, n h w$ and amew } \\
\hline$r=0$ & 37.97 & 32.25 & 35.07 & 40.78 \\
\hline$r=1$ & 10.34 & 17.98 & 20.16 & 24.69 \\
\hline$r=2$ & 2.81 & 7.60 & 9.14 & 12.53 \\
\hline
\end{tabular}

Notes: Sample 1993:Q1-2011:Q1; $r$ indicates the number of cointegrating vectors; the critical values of Johansen's trace tests are obtained by computing the relevant response surface as in Doornik (1998). For the VAR with $s r$, $n w$ and amew, the deterministic terms in the model are the constant and four spike dummies (1998:Q1, 2001:Q4, 2004:Q2 and 2009:Q3). See the notes on Table 4 for an explanation. For the VAR with $s r, n h w$ and amew, the deterministic terms in the model are the constant and three spike dummies (2001:Q4, 2005:Q2 and 2009:Q3). For an explanation of the first and third dummies, see notes Table 4. The second dummy is included for the peak in house price changes (S\&P Case-Shiller home price index expressed in year-over-year percentage change). The dummies are not restricted to the long-run. 
Table 8

Cointegration vector and loading parameter for VECM and cointegrating rank $r=1$ with restrictions.

\begin{tabular}{|c|c|c|c|c|c|}
\hline & $n w$ & $n h w$ & amew & $s r$ & cons \\
\hline \multicolumn{6}{|c|}{ VECM with $s r, n w$ and amew } \\
\hline$\hat{\beta}^{\prime}$ & $\begin{array}{r}0.143 \\
(4.53)\end{array}$ & - & $\begin{array}{r}0.297 \\
(2.88)\end{array}$ & $\begin{array}{l}1 \\
1\end{array}$ & $\begin{array}{l}-11.861 \\
(-8.15)\end{array}$ \\
\hline$\hat{\alpha}^{\prime}$ & $\begin{array}{c}-0.292 \\
(-0.92)\end{array}$ & - & $\begin{array}{c}-0.140 \\
(-1.67)\end{array}$ & $\begin{array}{c}-0.623 \\
(-4.62)\end{array}$ & \\
\hline \multicolumn{6}{|c|}{ VECM with $s r, n h w$ and amew } \\
\hline$\hat{\beta}^{\prime}$ & - & $\begin{array}{c}0.163 \\
(4.98)\end{array}$ & $\begin{array}{c}0.471 \\
(5.96)\end{array}$ & $\begin{array}{l}1 \\
1\end{array}$ & $\begin{array}{c}-11.431 \\
(-9.27)\end{array}$ \\
\hline$\hat{\alpha}^{\prime}$ & - & $\begin{array}{c}-0.249 \\
(-0.81)\end{array}$ & $\begin{array}{c}-0.173 \\
(-2.03)\end{array}$ & $\begin{array}{l}-0.591 \\
(-4.32)\end{array}$ & \\
\hline
\end{tabular}

Notes: Sample 1993:Q1-2011:Q1.t-Statistics in parentheses.

$\mathrm{sr}->\mathrm{sr}$
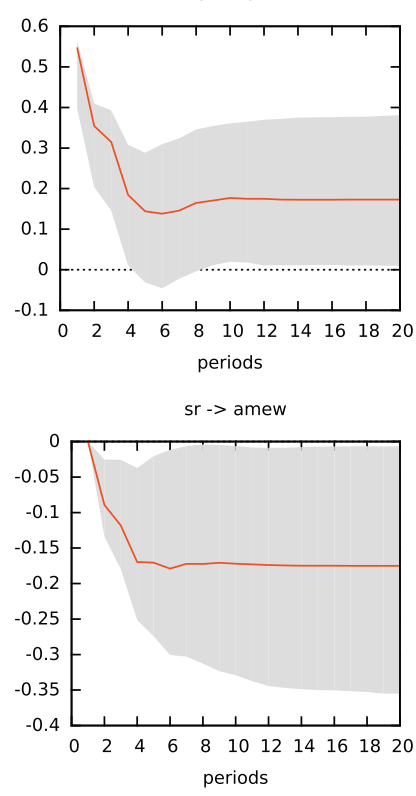

sr -> nw

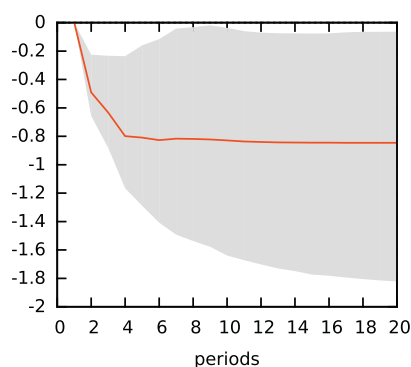

amew -> sr
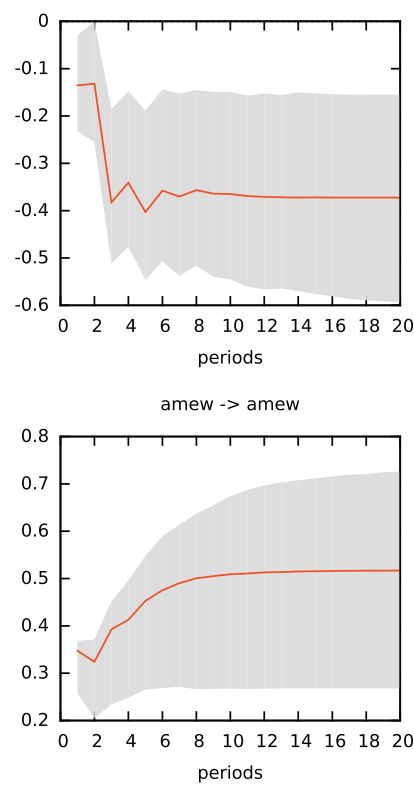

amew -> nw

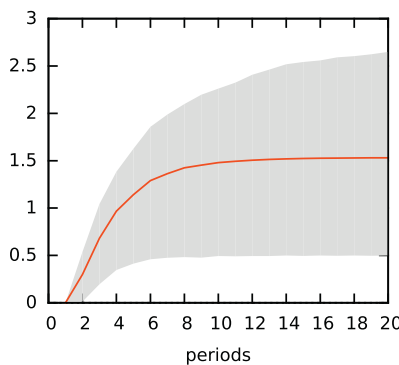

nw - > sr
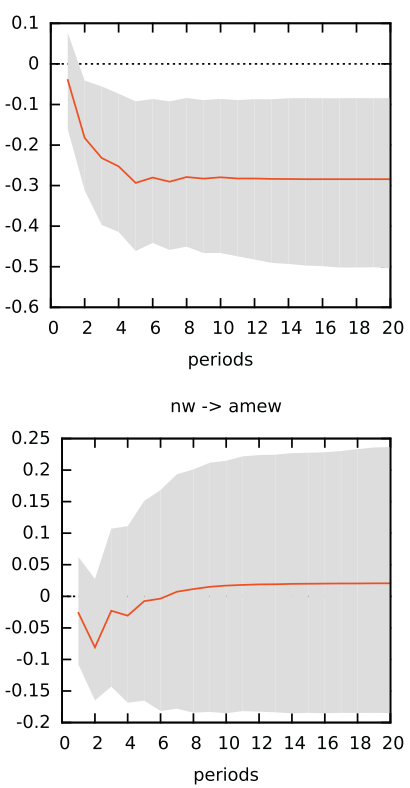

nw -> nw

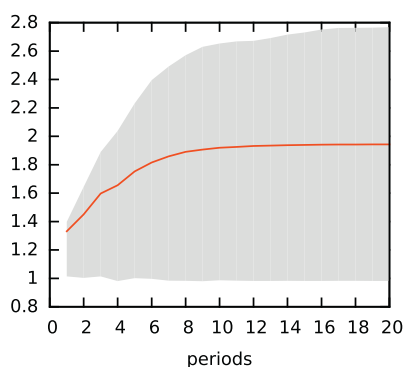

Fig. 1. Impulse response analysis for the VEC model with $s r$, amew and $n w$ variables with $95 \%$ hall bootstrap confidence intervals based on 2000 bootstrap replications. 

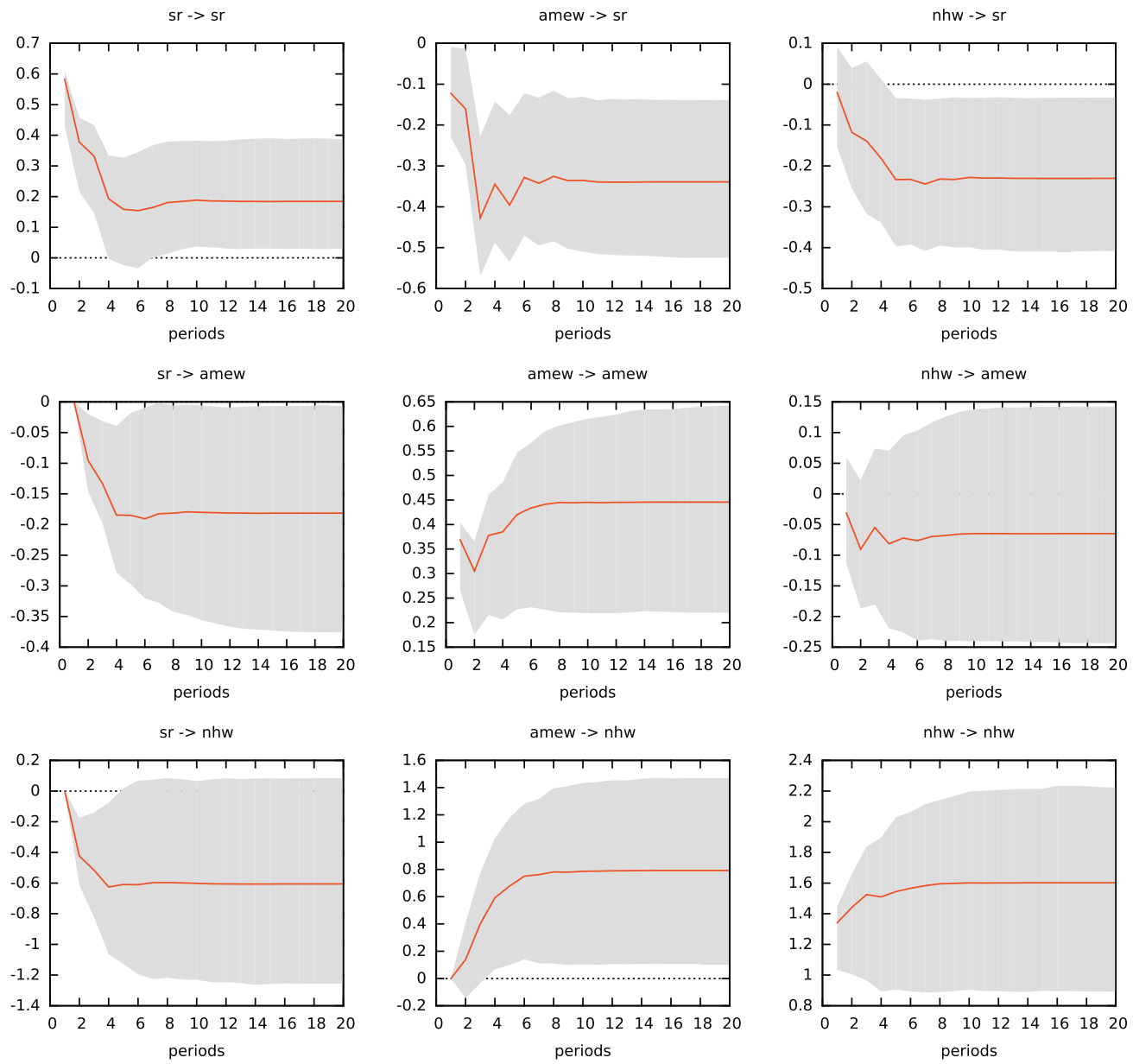

Fig. 2. Impulse response analysis for the VEC model with $s r$, amew and $n h w$ variables with $95 \%$ hall bootstrap confidence intervals based on 2000 bootstrap replications.
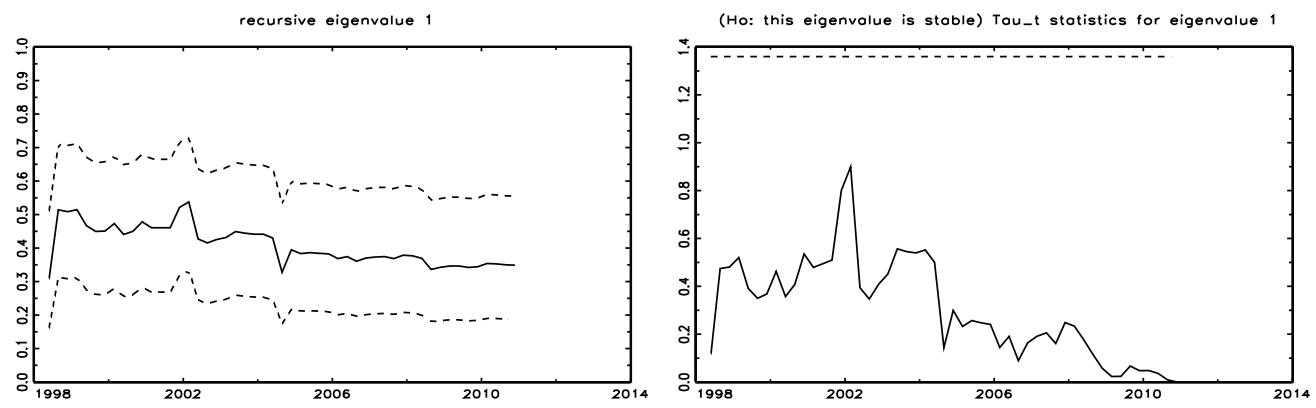

Fig. 3. Recursive eigenvalue analysis of VEC model with $s r$, amew and $n w$. Critical values for a $5 \%$ test level. 


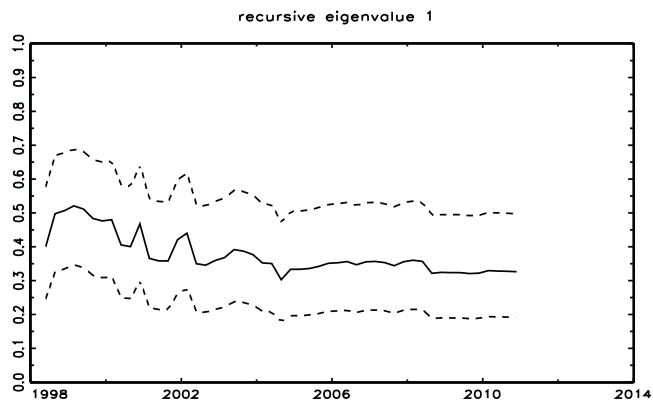

(Ho: this eigenvalue is stable) Tau_t statistics for eigenvalue 1

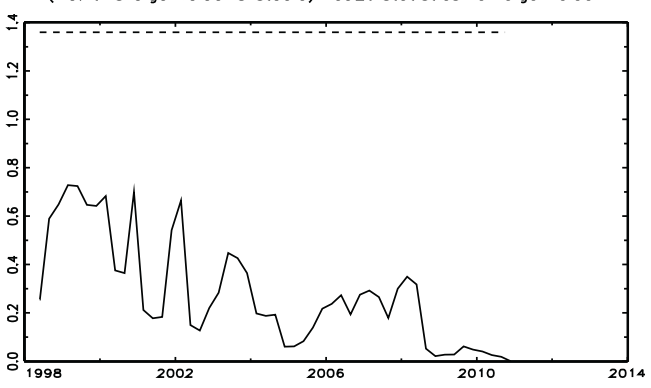

Fig. 4. Recursive tau analysis of VEC model with sr, amew and nhw. Critical values for a $5 \%$ test level.

On the basis of the previous findings, we proceed to estimate two VAR models with three variables. The first includes $s r$, amew and $n w$, and the second $s r$, amew and $n h w$. The information criteria suggest different lag orders. We opt for three lags on the basis of the diagnostic tests (see Table 6).

Next we test for cointegration and find that the null hypothesis of one cointegrating vector cannot be rejected at the conventional significance level (see Table 7). The cointegrating vector is then estimated for the two specifications (see Table 8). All the variables have the expected signs and the factor loading for $s r$ is negative and statistically significant, which implies that the long-run relationship for $s r$ holds and deviations from the long-run equilibrium are absorbed in less than two quarters in both specifications (the coefficient is equal to 0.6).

Having specified the reduced form model, we now turn to the structural analysis. Within the VECM framework, we use a Cholesky decomposition to identify the shocks assuming the following order of the variables: $n w$, amew and $s r$ in the first specification and $n h w$, amew and $s r$ in the second one. ${ }^{4}$ The findings indicate that a positive shock to the wealth components and to amew decreases $s r$ in both specifications as expected, although the response to amew is statistically significant only after two quarters in the VECM with non-housing wealth. We also find a negative response of wealth ( $n w$ or $n h w$ ) to a positive shock in $s r$ (see also Ludvigson et al., 2002), whereas a rise in sr leads to a reduction in mortgage equity withdrawal (although this effect is not statistically significant). On the whole, the impulse response analysis suggests that amew along with household wealth are important driving forces of the saving rate (see Figs. 1 and 2).

Finally, we test for the stability of the estimated systems. Hansen and Johansen (1999) have proposed recursive statistics for stability analysis in the context of a VECM model with cointegrated variables. Since the cointegrating rank is $r=1$, there is one non-zero eigenvalue. For both VECM specifications, the confidence intervals and the tau statistics $\tau_{T}^{(t)}\left(\eta_{1}\right)$ are plotted in Figs. 3 and 4 together with the critical values at the $5 \%$ level. The recursive eigenvalue appears to be fairly stable, and the values of $\tau_{T}^{(t)}\left(\eta_{1}\right)$ are considerably smaller than the critical values. Thus, the stability of the systems appears to be confirmed.

\section{Conclusions}

This paper contributes to the current literature on the behaviour of the US saving rate by focusing on the role of mortgage equity withdrawal. Whilst previous studies have analysed the relationship between the saving rate, mortgage equity withdrawal, net wealth and interest rates in a single equation error correction model, the present one estimates a vector error correction model since the assumption of exogeneity implicitly made for the right-hand side variables of a single equation model may not be valid for mortgage equity withdrawal and housing wealth. In particular, we estimate two dif-

\footnotetext{
4 The Cholesky decomposition is widely used in the empirical literature to identify structural shocks (see Rossi and Zubairy, 2011; Davis and Zhu, 2011; Gibson et al., 2012). Because the results can be sensitive to the order of the variables, Sims (1981) recommends checking whether they are robust to different orderings. Robustness is found in our case.
} 
ferent VECM specifications. The first includes net wealth, while the second distinguishes between the two components of the wealth, i.e. housing and non-housing wealth. We find a significant long-run relationship between the saving rate, wealth and mortgage equity withdrawal. These results contrast with those obtained in previous studies where mortgage equity withdrawal is not significant. In addition, the impulse response analysis shows that mortgage equity withdrawal is an important determinant of the dynamics of the saving rate in both VECMs. This has important policy implications, since it suggests that monetary authorities can influence consumption through this channel in addition to the traditional interest rate and asset prices/wealth effect ones. In other words, changes in interest rates appear to affect consumption not only through after-mortgage payments, household disposable income (the interest rate channel) and asset prices (the asset prices/wealth effect), but also through housing equity extraction. This implies that the effect of monetary policy on private spending is amplified through its impact on the equity extraction mechanism. Therefore, monetary authorities can exploit this additional channel for controlling demand and output in the economy.

\section{References}

Bakshi, G.S., Chen, Z., 1996. Inflation, asset prices, and the term structure of interest rates in monetary economies. Review of Financial Studies 9, 241-276.

Canner, G.B., Karen, D., Passmore, W., 2002. Mortgage refinancing in 2001 and early 2002. Federal Reserve Bulletin, 469-481.

Catte, P., Girouard, N., Price, R., Andre, C., 2004. Housing markets, wealth and the business cycle, OCED Economics Department Working Paper No. 394.

Cynamon, B.Z., Fazzari, S.M., 2008. Household debt in the consumer age: source of growth-risk of collapse. Capitalism and Society 3, 1-30, Article 3.

Davis, P.E., Zhu, H., 2011. Bank lending and commercial property cycles: some cross-country evidence. Journal of International Money and Finance 30, 1-21.

Disney, R., Gathergood, J., 2009. House price volatility and household indebtedness in the US and the UK, Centre for Finance and Credit Markets, Working Paper, 09/02.

Donihue, M., Avramenko, A., 2007. Decomposing consumer wealth effects: evidence on the role of real estate assets. B.E. Journal of Macroeconomics (Topics) 7, Article 25.

Doornik, J.A., 1998. Approximations to the asymptotic distributions of cointegration tests. Journal of Economic Surveys 12 , 573-593.

Duca, J.V., Kumar, A., 2011. Financial literacy and mortgage equity withdrawals, Federal Reserve Bank of Dallas Working Paper No. 1110.

Elliot, G., Rothenberg, T., Stock, J., 1996. Efficient tests for an autoregressive unit root. Econometrica 64, 813-836.

Ericsson, N.R., MacKinnon, J.G., 2002. Distributions of error correction tests for cointegration. Econometrics Journal 5, $285-318$.

Gibson, H.D., Hall, S.G., Tavlas, G.S., 2012. The Greek financial crisis: growing imbalances and sovereign spreads. Journal of International Money and Finance 31, 498-516.

Girouard, N., 2010. Housing and mortgage markets: an OCED perspective. In: Smith, S.J., Searle, B.A. (Eds.), The Blackwell Companion to the Economics of Housing: The Housing Wealth of Nations. Blackwell Publishing.

Greenspan, A., Kennedy, J., 2005. Estimates of home mortgage originations, repayments, and debt on one-to-four family residences, Finance and Economic Discussion Series No. 2005-41, Board of Governors of Federal Reserve System.

Greenspan, A., Kennedy, J., 2008. Sources and uses of equity extracted from homes. Oxford Review of Economic Policy 24, $120-144$

Greenwood, J., Jovanovic, B., 1999. The information-technology revolution and the stock market. American Economic Review 89, 116-122.

Hansen, H., Johansen, S., 1999. Some tests for parameter constancy in cointegrated VAR-models. Econometrics Journal 2 , 306-333.

Hatzius, J., 2006. Housing holds the key to fed policy, Global Economics Paper No. 37, Goldman Sachs.

Iacoviello, M., 2011. Housing wealth and consumption, International Finance Discussion Papers 1027. Board of Governors of the Federal Reserve System (U.S.).

Katona, G., 1975. Psychological Economics. Elsevier, New York.

Kim, Y.K., 2011. The macroeconomic implications of households debt: an empirical analysis, Trinity College Department of Economics, Working Paper No. 11-03.

Kishor, N.K., 2007. Does consumption respond more to housing wealth than to financial market wealth? If so, why? Journal of Real Estate Finance and Economics 35, 427-448.

Klyuev, V., Mills, P., 2010. Is housing wealth an "ATM"?: International trends. In: Smith, S.J., Searle, B.A. (Eds.), The Blackwell Companion to the Economics of Housing: The Housing Wealth of Nations. Blackwell Publishing.

Johansen, S., 1998. Statistical analysis of cointegration vectors. Journal of Economic Dynamics and Control 12, 231-254.

Juselius, K., 2001. Big Shocks, Outliers and Interventions. A Cointegration and Common Trends Analysis of Daily Bond Rates. European University Institute, Florence, Mimeo.

Juselius, K., 2006. The Cointegrated VAR Model: Methodology and Applications. Oxford University Press, Oxford.

Lusardi, A., Skinner, J., Venti, S., 2001. Saving puzzles and saving policies in the United States. Oxford Review of Economic Policy $17,95-115$.

Ludvigson, S., Steindel, C., Lettau, M., 2002. Monetary policy transmission through the consumption-wealth channel. FRBNY Economic Policy Review (May), 117-133. 
Lütkepohl, H., 2004. Vector autoregressive and vector error correction models. In: Lütkepohl, H., Krätzig, M. (Eds.), Applied Time Series Econometrics. Cambridge University Press.

Lütkepohl, H., Reimers, H.E., 1992. Impulse response analysis of cointegrated systems. Journal of Economic Dynamics and Co $16,53-78$.

MacKinnon, J.G., 1996. Numerical distribution functions for unit root and cointegration tests. Journal of Applied Econome 11, 601-618

Mankiw, N.G., Ball, L., 2011. Macroeconomics and the Financial System. Worth Publisher, New York.

Mian, A., Sufi, A., 2011. House prices, home equity-based borrowing, and the US household leverage crisis. American Economic Review 101, 2132-2156.

Mishkin, F.S., 2007. Housing and the monetary transmission mechanism, National Bureau of Economic Research Working Paper No. 13518.

Muellbauer, J., 2008. Housing, credit and consumer expenditure, CEPR Discussion Paper No. 6782.

Paradiso, A., Casadio, P., Rao, B.B., 2012. US inflation and consumption: a long-term perspective with a level shift. Economic Modelling 29, 1837-1849.

Paradiso, A., 2013. What caused the equity withdrawal mechanism? An investigation using threshold cointegration and error correction. Applied Financial Economics 23, 139-148.

Poterba, J., 2000. Stock market wealth and consumption. Journal of Economic Perspectives 14, 99-118.

Rossi, B., Zubairy, S., 2011. What is the importance of monetary and fiscal shocks in explaining U.S. macroeconomic fluctuations. Journal of Money, Credit and Banking 43, 1247-1270.

Schwert, G.W., 1989. Tests for unit roots: a Monte Carlo investigation. Journal of Business \& Economic Statistics 7, 147-159.

Sims, C.A., 1981. An autoregressive index model for the U.S. 1948-1975. In: Kmenta, J., Ramsey, J.B. (Eds.), Large-Scale MacroEconometric Models. North-Holland, Amsterdam, pp. 283-327.

Smith, S.J., Searle, B.A., 2008. Dematerialising money? Observations on the flow of wealth from housing to other things. Housing Studies 23, 21-43.

Urbain, J.P., 1992. On weak exogeneity in error correction models. Oxford Bulletin of Economics and Stati 54, $187-207$. 